\title{
Ammonia Toxicity to Rinuak (Gobiopterus brachypterus) of Lake Maninjau
}

\author{
Gunawan Pratama Yoga ${ }^{a} *$, Octavianto Samir ${ }^{\text {a }}$ \\ ${ }^{a}$ Research Center for Limnology LIPI; Kompleks LIPI Cibinong, Jalan Raya Bogor, Km. 46, Cibinong 16911; \\ *yoga@limnologi.lipi.go.id
}

Received 07 December 2020

Accepted 13 December 2020

Published 17 December 2020

\begin{abstract}
Rinuak (Gobiopterus brachypterus) has an important economic value for local communities in Lake Maninjau - West Sumatra. The catch of G. brachypterus is decreasing along with the decline of the water quality. Ammonia is considered one of the most toxic pollutants in the aquatic ecosystem. It can be produced from the natural decomposition of organic matter or excreted by aquatic organisms as a nitrogenous waste product. Therefore, the information about toxicity ammonia in G. brachypterus is important as a management tool for fish conservation in Lake Maninjau. This research was aimed to find the $\mathrm{LC}_{50}$ value of ammonia in G. brachypterus. A static acute toxicity test was conducted for 96 hours. The fish were exposed to different test chemical concentration level for 96 hours, under static conditions. Mortality was recorded and concentration killed $50 \%$ of the fish was determined as $\mathrm{LC}_{50}-96 \mathrm{~h}$, No Observed Effect Concentration (NOEC), and Lowest Observed Effect Concentration (LOEC). Values of LC $_{50}-96 \mathrm{~h}$, No Observed Effect Concentration (NOEC) and Lowest Observed Effect Concentration (LOEC) were $11.62 \mathrm{mg} / \mathrm{L} \mathrm{TAN}$ or $0.27 \mathrm{mg} / \mathrm{L} \mathrm{NH}_{3}, 5 \mathrm{mg} / \mathrm{L}$ TAN or $0.12 \mathrm{mg} / \mathrm{L} \mathrm{NH}_{3}$ and $16 \mathrm{mg} / \mathrm{L}$ TAN or $0,37 \mathrm{mg} / \mathrm{L} \mathrm{NH}_{3}$, respectively. Ammonia's Maximum Acceptable Tolerant Concentration (MATC) for $G$. brachypterus was $8.9 \mathrm{mg} / \mathrm{L}$ TAN or $0.21 \mathrm{mg} / \mathrm{L} \mathrm{NH}_{3}$. The acute toxicity result showed that Rinuak ( $G$. brachypterus) was sensitive to ammonia. The information about ammonia toxicity data is important for the determination of water quality guidelines in Lake Maninjau.
\end{abstract}

Keywords: Acute toxicity, Ammonia, $\mathrm{LC}_{50}$, Gobiopterus brachypterus

\section{INTRODUCTION}

Lake Maninjau is a tecto-volcanic lake located in West Sumatra. The lake was a well-known tourist destination in the past. However, since cage aquaculture was introduced in 1992 and then expanded in 1995 (Yosmeri, 2013), the water quality of the lake tends to be degraded, which is caused by excess fish food and fish wastes. The contribution of nutrients from the aquaculture has been counted around 400

* Corresponding Author
E-mail: yoga@limnologi.lipi.go.id

CCMLI 2020 tons/year, and about ninety five percent of that were nitrogen and phosphorus (Azis, 2016).

In the aquatic ecosystem, ammonia is considered one of the most toxic pollutants. It can be produced from the natural decomposition of organic matter or excreted by aquatic organisms as a nitrogenous waste product. Anthropogenic activities also created many nitrogenous wastes, which significantly deteriorated the water quality condition of freshwater. According to (Alabaster \& Lloyd, 1982) and (Bhakta, 2006), enormous amounts of ammonia are produced by fertilizers production and usage and animal husbandry. 
Therefore, ammonia can enter aquatic environments through many sources such as sewage, animal and industrial wastes, and bacterial activity (Eddy, 2005).

Elevated ammonia concentration in freshwater can cause toxic effects on aquatic organisms. Ammonia concentration in the blood plasma of most freshwater fish is about $0.15-0.3 \mathrm{mmol} / \mathrm{L}$. Elevation of its concentration in the body can cause an imbalance of ionic regulation (Eddy, 2005); proliferation in gill tissues, increased ventilation rates, and damage to the gill epithelium, reduction in blood oxygen-carrying capacity due to progressive acidosis (Russo, 1985), uncoupling oxidative phosphorylation causing inhibition of production and depletion of adenosine triphosphate (ATP) in the brain (Carmago \& Alonso, 2006), and the disruption of osmoregulatory and circulatory activity disrupting normal metabolic functioning of the liver and kidneys (Arillo et al., 1981), (Tomasso et al., 1980).

Ammonia toxicity, which usually expresses Total Ammonia Nitrogen (TAN) in aquatic environments, increases with water's $\mathrm{pH}$ (Randall \& Tsui, 2002). The TAN is total sum of ammonium $\left(\mathrm{NH}_{4}{ }^{+}\right)$and ammonia $\left(\mathrm{NH}_{3}\right)$; the latter is considered as a product of body protein and nucleic acid biochemical degradation (Mardones et al., 2019).

Every aquatic life has a specific tolerance level of ammonia concentration. Knowing the concentration of ammonia that causes aquatic life mortality, especially fish is essential to protect them from vanishing. Toxicity tests, typically single species, single toxicant, are designed to assess the potential toxicity and identify possible adverse effects on human health or the environment (USEPA, 1998).

Rinuak (Gobiopterus brachypterus) is one of the consumable fish in Lake Maninjau; another favorable fish is Bada (Rasbora spp.). This anchovy - like fish is the main ingredient for typical foods such as palai (fish wrapped in a banana leaf and roasted) and dendeng (fish jerky). Thus, Rinuak has high demand and becomes a valuable and also essential economy for local people around the lake. Taxonomically, Rinuak is classified in the Perciformes ordo and Gobiidae family. This translucent and tiny fish has a maximal total length of $2.9 \mathrm{~cm}$ (Kottelat et al., 1993). Generally, Rinuak can be found in such Indonesian tropical waters including Sumatra and Java. Roesma et al. (2020) recorded the same species of Rinuak, found among three lakes in Sumatra; Maninjau, Singkarak, and Siais, while Imam (2011) found this species in Lake Ranu Grati, East Java. On the other hand, Rinuak is also found overseas, in Singapore and Sri Lanka (Kwik, 2015 \& Larson et al., 2008).

Rinuak lives in freshwater with calm current water and planted by aquatic macrophytes, used as a shelter or refuge. In the shallow part of water, only a few Rinuak can be found during the daytime. While at night, these gobies come up from the deeper part of the water. Rinuak lives in a habitat with such water quality parameters: temperature ranged between $25-35.8^{\circ} \mathrm{C}, \mathrm{pH}$ value was 7.9 , and the electric conductivity was $680 \mu \mathrm{s} / \mathrm{cm}$ (Ott, 2011).

As part of National priority Research on Lake Restoration Technology to support aquaculture and tourism in Lake Maninjau, Rinuak conservation through domestication is an effort to conserve the fish. To support the domestication effort, therefore, this research was aimed to calculate the $\mathrm{LC}_{50}$ value of ammonia to Rinuak (G.brachypterus) and to estimate No Observed Effect Concentration (NOEC), Lowest Observed Effect Concentration (LOEC), and Maximum Acceptable Tolerant Concentration (MATC) values of ammonia to Rinuak ( $G$. brachypterus). Those values can be used for the calculation of reference to water quality guidelines for ammonia.

\section{METHODS}

\section{Time and Location}

Acute toxicity test was conducted in the Unit for Technology Transfer of Lake Restorations Indonesian Institute of Sciences (LATPD LIPI) at Tanjung Raya, West Sumatra, Indonesia, on 
March $19^{\text {th }}-28^{\text {th, }} 2019$.

\section{Fish Handling}

Rinuak (G. brachypterus) used for toxicity tests were provided from aquaculture facilities in LATPD LIPI. Eight hundred fishes were prepared for the test. Acclimatization was conducted for two weeks prior to the test. During acclimatization and experimentation, The fish were fed with a commercial fish diet. Fish were fed in the morning and afternoon, water quality and mortality were recorded during the acclimatization period. A day before the toxicity test was conducted, fish was stopped from feeding.

\section{Chemicals}

Ammonium Chloride $\left(\mathrm{NH}_{4} \mathrm{Cl}\right.$, HIMEDIA $)$ was used as a source of ammonia during toxicity tests. Ammonium Chloride was diluted by aquadest to made Ammonium stock solution (10.000 ppm). Agriculture lime $\left(\mathrm{CaCO}_{3}\right)$ was used to stabilized water $\mathrm{pH}$ to be around 7 during the toxicity test.

\section{Bioassay}

Acute toxicity tests to determine the Lethal Concentration $\left(\mathrm{LC}_{50}\right)$ of ammonia to Rinuak fish were run according to USEPA (2002). The assay was conducted in two steps, range - finding, and definitive test. A series of ammonia concentrations were used in a range - finding test to determine the short - term lethal ammonia toxicity to Rinuak. Eighteen glass aquariums, volume 30 liter, filled with aged, aerated tap water as the diluent of ammonia, were prepared for this study. The test was conducted for 48 hours, and the dead fish were recorded at the end of the test. Ammonia concentration series in range - finding test were $0 \mathrm{mg} / \mathrm{L}, 0.5 \mathrm{mg} / \mathrm{L}, 5$ $\mathrm{mg} / \mathrm{L}, 50 \mathrm{mg} / \mathrm{L}$ and $500 \mathrm{mg} / \mathrm{L}$, and its made duplo. Fish mortality from the range - finding test was used to determine the tentative $\mathrm{LC}_{50}$. Tentative $\mathrm{LC}_{50}$ result from range finding test was used to determine ammonia concentrations in acute definitive test.

On a range - finding test, eight fish were exposed to the toxicant in each aquarium, and fish mortality was recorded every 24 hours for 48 hours. Dead fish was removed immediately during observation. Fish mortality data from the range - finding test was calculated to determine the ammonia concentration sequence used in the definitive test.

Based on the range - finding test, ammonia concentration sequence in definitive test were 5 $\mathrm{mg} / \mathrm{L}, 16 \mathrm{mg} / \mathrm{L}, 27 \mathrm{mg} / \mathrm{L}, 38 \mathrm{mg} / \mathrm{L}$ and $50 \mathrm{mg} / \mathrm{L}$, with 3 replicates. Twenty fishes in each aquarium were exposed to those ammonia concentrations. Fish dead were recorded and removed every 24 hours. Fish mortality data then were used to calculate $\mathrm{LC}_{50} 96 \mathrm{~h}$. Acute toxicity test was conducted on a static condition, without water renewal. Fish feeding was not allowed during the test. The test was valid when fish mortality in control is less than $10 \%$ of the amount of exposed fish.

\section{Analysis}

Probit analysis was used to calculate $\mathrm{LC}_{50} 96 \mathrm{~h}$ from fish mortality data. Probit analysis was established using software Simply Probit version 1.2 (PISCES Conservation Ltd, 2005).

No Observed Effect Concentration (NOEC) and the Lowest Effect Concentration (LOEC) were calculated using one-way ANOVA followed by Tukey analysis in excel. NOEC and LOEC were used to calculate the Maximum Acceptable Toxicant Concentration (MATC). MATC is a value calculated through acute toxicity tests to set water quality regulations to protect aquatic life. The MATC is reported as the geometric mean of the NOEC and LOEC (Rand, 1995).

\section{Water Quality Parameters}

Physico-chemical parameters measured during the toxicity test were temperature $\left({ }^{\circ} \mathrm{C}\right), \mathrm{pH}$, and Dissolved Oxygen/ DO (mg/L). Measurement was conducted using a portable Water Quality Checker (WQC) HORIBA U50. Physico - chemical parameters were measured every day at $10 \mathrm{am}$. 


\section{RESULTS AND DISCUSSION}

Rinuak range - finding test results showed that ammonia concentrations of $50 \mathrm{mg} / \mathrm{L}$ and 500 $\mathrm{mg} / \mathrm{L}$ were very toxic to the fish. Those concentrations killed all fish in the test chambers after 24 hours of exposure. Table 1 shows the mortality of Rinuak during the range - finding test. Results of the range - finding test indicated that critical fish mortality occurred between 5 $50 \mathrm{mg} / \mathrm{L}$. Therefore, those concentrations were considered to be the lowest and the highest concentration in the definitive test. The definitive acute toxicity test showed that $\mathrm{LC}_{50} 96 \mathrm{~h}$ of Rinuak for Total Ammonia Nitrogen was 11.62 $\mathrm{mg} / \mathrm{L}$ with lower confidence limit and upper confidence limit were $9.90 \mathrm{mg} / \mathrm{L}$ and $13.27 \mathrm{mg} / \mathrm{L}$, respectively.

Table 1. Average mortality of Rinuak ( $G$. brachypterus) during Range-finding Test

\begin{tabular}{ccc}
\hline TAN Concentration & \multicolumn{2}{c}{ Mortality (fish) } \\
\cline { 2 - 3 }$(\mathrm{mg} / \mathrm{l})$ & 24 hours & 48 hours \\
\hline 0 & 0 & 0 \\
0.5 & 0 & 0 \\
5 & 2 & 2 \\
50 & 8 & 8 \\
500 & 8 & 8 \\
\hline
\end{tabular}

According to temperature and $\mathrm{pH}$ measurement during the acute definitive test, TAN value was equal to $0.27 \mathrm{mg} / \mathrm{L} \mathrm{NH}_{3}-\mathrm{N}$ with a lower confidence limit, and the upper confidence limit was $0.23 \mathrm{mg} / \mathrm{L} \mathrm{NH}_{3}-\mathrm{N}$ and $0.31 \mathrm{mg} / \mathrm{L} \mathrm{NH}_{3}-$ $\mathrm{N}$. Table 2 shows the mortality of Rinuak during the definitive test.

According to Rinuak mortality in the definitive acute toxicity test, No Observed Effect Concentration (NOEC) and the Lowest Effect Concentration (LOEC) values were $5 \mathrm{mg} / \mathrm{L}$ TAN $\left(0.12 \mathrm{mg} / \mathrm{L} \mathrm{NH} \mathrm{NH}_{3} \mathrm{~N}\right)$ and $16 \mathrm{mg} / \mathrm{L}$ TAN $(0.37$ $\mathrm{mg} / \mathrm{L} \quad \mathrm{NH}_{3}-\mathrm{N}$ ), respectively (Table 3). The MATC of ammonia to Rinuak was $8.9 \mathrm{mg} / \mathrm{L}$ TAN (0.21 mg/L NH $3-\mathrm{N})$.
Table 2. Mortality of Rinuak during Definitive Toxicity Test 96 hours.

\begin{tabular}{ccccc}
\hline TAN & \multicolumn{4}{c}{ Mortality (fish) } \\
\cline { 2 - 5 } $\begin{array}{c}\text { Concentration } \\
(\mathrm{mg} / \mathrm{l})\end{array}$ & $\begin{array}{c}24 \\
\text { hours }\end{array}$ & $\begin{array}{c}48 \\
\text { hours }\end{array}$ & $\begin{array}{c}72 \\
\text { hours }\end{array}$ & $\begin{array}{c}96 \\
\text { hours }\end{array}$ \\
\hline 0 & 1 & 1 & 1 & 1 \\
5 & 1 & 1 & 1 & 1 \\
16 & 14 & 14 & 14 & 14 \\
27 & 20 & 20 & 20 & 20 \\
38 & 20 & 20 & 20 & 20 \\
50 & 20 & 20 & 20 & 20 \\
\hline
\end{tabular}

Table 3. One way ANOVA Result of Rinuak ( $G$. brachypterus ) mortality during Definitive Toxicity Test 96 hours.

\begin{tabular}{ccc}
\hline $\begin{array}{c}\text { TAN } \\
\text { Concentration } \\
(\mathrm{mg} / \mathrm{l})\end{array}$ & $\begin{array}{c}\text { Mortality } \\
\text { Rate }\end{array}$ & Annotation \\
\hline 0 & 0.67 & $\mathrm{a}$ \\
$5 \mathrm{mg} / 1$ & 1 & $\mathrm{a}^{*}$ \\
$16 \mathrm{mg} / 1$ & 13.67 & $\mathrm{~b}^{* *}$ \\
$27 \mathrm{mg} / 1$ & 20 & $\mathrm{c}$ \\
$38 \mathrm{mg} / 1$ & 20 & $\mathrm{c}$ \\
$50 \mathrm{mg} / 1$ & 20 & $\mathrm{c}$ \\
\hline
\end{tabular}

$$
\begin{array}{r}
\text { Note: } * \text { NOEC } \\
* * \text { LOEC }
\end{array}
$$

Rinuak (G. brachypterus) is relatively sensitive to ammonia. The $\mathrm{LC}_{50} 96 \mathrm{~h}$ value was lower than several freshwater fish have been tested previously. Compared to some freshwater fish such as Catlacatla, Cyprinus carpio, Oreochromis mossambica, elver (Anguilla bicolor), and Rasbora maninjau, the $\mathrm{LC}_{50} 96 \mathrm{~h}$ value of Rinuak is lower. However, that value was higher than the LC50 of ammonia to Labeobata (Table 4).

For the aquatic living, un-ionized ammonia $\left(\mathrm{NH}_{3}-\mathrm{N}\right)$ is considered as the most toxic fraction of Total Ammonia Nitrogen (TAN) (USEPA, 1998). $\mathrm{LC}_{50}$ 96h of $\mathrm{NH}_{3}-\mathrm{N}$ for Rinuak $(G$ brachypterus), $0.27 \mathrm{mg} / \mathrm{L} \mathrm{NH}_{3}-\mathrm{N}$, is comparable to Oncorhynchus mykiss of $0.291 \mathrm{mg} / \mathrm{L} \mathrm{NH}-\mathrm{N}$ (Thurston \& Russo, 1983), Salmo trutta was of $0.592 \mathrm{mg} / \mathrm{L} \mathrm{NH}_{3}-\mathrm{N}$, Prosopium williamsoni was of $0.358 \mathrm{mg} / \mathrm{L} \mathrm{NH}_{3}-\mathrm{N}$ (USEPA, 2013), and 
Ictalurus punctatus that was of $0.50 \mathrm{mg} / \mathrm{L} \mathrm{NH}_{3}-\mathrm{N}$ (Mardones et al., 2019), which were originated from the temperate region.

Table 4. $\mathrm{LC}_{50}$ of ammonia to several freshwater fish

\begin{tabular}{|c|c|c|c|}
\hline No & Fish & $\begin{array}{c}\mathrm{LC}_{50} \\
\text { ammonia }\end{array}$ & Source \\
\hline 1 & Catlacatla & $\begin{array}{l}15 \mathrm{mg} / \mathrm{L} \\
\text { TAN }\end{array}$ & $\begin{array}{l}\text { (Bhakta, } \\
\text { 2006) }\end{array}$ \\
\hline 2 & $\begin{array}{l}\text { Cyprinus } \\
\text { carpio }\end{array}$ & $\begin{array}{l}25 \mathrm{mg} / \mathrm{L} \\
\text { TAN }\end{array}$ & $\begin{array}{l}\text { (Bhakta, } \\
\text { 2006) }\end{array}$ \\
\hline 3 & $\begin{array}{l}\text { Oreochromis } \\
\text { mossambica }\end{array}$ & $\begin{array}{l}30 \mathrm{mg} / \mathrm{L} \\
\text { TAN }\end{array}$ & $\begin{array}{l}\text { (Bhakta, } \\
\text { 2006) }\end{array}$ \\
\hline 4 & Labeobata & $\begin{array}{l}10 \mathrm{mg} / \mathrm{L} \\
\text { TAN }\end{array}$ & $\begin{array}{l}\text { (Bhakta, } \\
\text { 2006) }\end{array}$ \\
\hline 5 & $\begin{array}{l}\text { Elver } \\
\text { (Anguilla } \\
\text { bicolor) }\end{array}$ & $\begin{array}{l}467.4 \\
\mathrm{mg} / \mathrm{L} \\
\text { TAN ; } \\
0,466 \\
\mathrm{mg} / \mathrm{L} \\
\mathrm{NH} 3-\mathrm{N}\end{array}$ & $\begin{array}{l}\text { (Yoga \& } \\
\text { Nursodiyanti, } \\
2018 \text { ) }\end{array}$ \\
\hline 6 & $\begin{array}{l}\text { Rasbora } \\
\text { maninjau }\end{array}$ & $\begin{array}{l}29.9 \\
\mathrm{mg} / \mathrm{L} \\
\text { TAN }\end{array}$ & $\begin{array}{l}\text { (Yoga \& } \\
\text { Samir, 2020) }\end{array}$ \\
\hline
\end{tabular}

Compared to some ammonia quality standards for freshwater, which are used in some countries, it shows that Rinuak is tolerable to un-ionized ammonia, because the MATC value, $0.21 \mathrm{mg} / \mathrm{L}$ $\mathrm{NH}_{3}-\mathrm{N}$, is higher than ammonia concentration for water quality criteria in Indonesia, $\leq 0.02 \mathrm{mg} / \mathrm{L}$ $\mathrm{NH}_{3}-\mathrm{N}$, Canada, $0.019 \mathrm{mg} / \mathrm{L} \mathrm{NH}_{3}-\mathrm{N}$, USEPA, $0.02 \mathrm{mg} / \mathrm{L} \mathrm{NH}_{3}-\mathrm{N}$.

MATC is useful for setting regulatory guidelines for protecting aquatic life through water quality criteria in which only acute toxicity data exists.

Generally, physico - chemical measurements during the test fit to the range of Rinuak natural habitat. Water temperature, $\mathrm{pH}$ and dissolved oxygen in toxicity test tank were described in Table 5. Gobiopterus brachypterus in Lake
Maninjau live in temperature between 28.6 - 31.1 degrees Celsius, $\mathrm{pH}$ value between $7.4-7.7$ and dissolved oxygen concentration between 6.73 $8.47 \mathrm{mg} / \mathrm{L}$ (Tanjung, 2015).

Table 5. Physico - chemical measurement result during Toxicity Tests

\begin{tabular}{ccc}
\hline Parameter & Unit & Value \\
\hline Temperature & ${ }^{\circ} \mathrm{C}$ & $26.29(24.2-27.9)$ \\
$\mathrm{pH}$ & - & $7.65(7.41-8.26)$ \\
Dissolved Oxygen & $\mathrm{mg} / \mathrm{l}$ & $4.98(4.31-5.82)$ \\
\hline
\end{tabular}

\section{CONCLUSION}

The acute toxicity test result to ammonia, LC50 96h of Rinuak (Gobiopterus brachypterus) is $11.62 \mathrm{mg} / \mathrm{L} \quad$ TAN $\left(0.27 \mathrm{mg} / \mathrm{L} \quad \mathrm{NH}_{3}-\mathrm{N}\right)$. According to that value, Rinuak (Gobiopterus brachypterus) is relatively sensitive to ammonia compared to other freshwater fish species.

No Observed Effect Concentration (NOEC) of ammonia to Rinuak (G. brachypterus) is $5 \mathrm{mg} / \mathrm{L}$ TAN $\left(0.12 \mathrm{mg} / \mathrm{L} \mathrm{NH}_{3}-\mathrm{N}\right)$, while the lowest impact concentration (LOEC) of the ammonia to rinuak (G. brachypterus) is $16 \mathrm{mg} / \mathrm{L}$ TAN $(0.37$ $\left.\mathrm{mg} / \mathrm{L} \mathrm{NH}_{3}-\mathrm{N}\right)$. Based on those values, the Maximum Acceptable Toxicant Concentration (MATC) of ammonia to Rinuak (G. brachypterus) is $8.9 \mathrm{mg} / \mathrm{L} \mathrm{TAN}\left(0.21 \mathrm{mg} / \mathrm{L} \mathrm{NH}_{3}-\mathrm{N}\right)$.

\section{ACKNOWLEDGEMENTS}

This study was part of the National Priority Program and was funded by the Roster of Budget Executive (DIPA) of Research Center for Limnology, Indonesian Institute of Sciences (LIPI) 2019 fiscal year. The authors are indebted to Mr. Nasrul Muit as a research technician who has helped the authors set up the experimental equipment and the toxicity test. The authors also appreciate all staff of LIPI in Maninjau, who technically have supported this research. 


\section{REFERENCES}

Alabaster JS \& Lloyd R. 1982. Water Quality Criteria for Freshwater Fish. Food and Agricultural Organization of the United Nation, London, Boston.

Arillo A, Margiocco C, Melodia F, Mensi P, and Schenone G. 1981. Ammonia toxicity mechanism in fish: Studies on rainbow trout (Salmo gairdneri Richardson.). Ecotoxicology and environmental safety, 5(3), 316-328. DOI: 10.1016/0147-6513(81)90006-3.

Azis CH. 2016. Ecotechnology and ecosystembased management tools as alternative solutions to reduce risks of ecosystem disaster and fish kill in Lake Maninjau. Proc. Nat. Sem. Limnology.

Bhakta JN. 2006. Ammonia Toxicity to Four Freshwater Fish Species: Catlacatla, Labeobata, Cyprinus carpio, and Oreochromis mossambica. Electronic Journal of Biology, 2(3), 39 -41.

Carmago J \& Alonso A. 2006. Ecological and toxicological effects of inorganic nitrogen pollution in aquatic ecosystems: A global assessment. Environment international, 32, 831849.

Eddy FB. 2005. Ammonia in estuaries and effects on fish. Journal of Fish Biology, 67, 1495-1513. DOI: $10.1111 / \mathrm{j} .1095-8649.2005 .00930 . \mathrm{x}$

Imam M. 2011. Variasi Morfologi pada Ikan Lempuk (Gobiopterus brachypterus) di Danau Ranu Grati Pasuruan. Magister Thesis ed. Universitas Brawijaya. http://repository.ub.ac.id/157878/

Kottelat M, Kartikasari SN, Whitten T, and Wirjoatmodjo S. 1993. Freshwater Fishes of Western Indonesia and Sulawesi. Periplus Editions, Singapore.

Kwik JTB \& Yeo DCJ. 2015. Differences in fish assemblages in protected and non-protected freshwater streams in a tropical urbanized country. Hydrobiologia, 762, 143-156. DOI: $10.1007 / \mathrm{s} 10750-015-2344-8$

Larson HK, Jaafar Z, and Lim KKP. 2008. An Annotated Checklist of The Gobioid Fishes of Singapore. The Raffles Bulletin of Zoology, 56(1), 135-155.

Mardones A, González M, Rivas-Mancilla C, Vega R, Augsburger A, Encina F, and De los Ríos P. 2019. Determination of acute toxicity of ammonium in juvenile Patagonian blenny (Eleginopsmaclovinus). Brazilian journal of biology, 79(4), 646-650. DOI: 10.1590/1519-
6984.186991

Ott G. 2011. First records of Gobiopterus brachypterus and Mugilogobius tigrinus from Sri Lanka (Teleostei, Perciformes, Gobiidae: Gobionellinae). Bulletin of Fish Biology, 13(1), 71-75.

Rand GM. 1995. Fundamentals of Aquatic Toxicology (2nd ed.). CRC Press, Boca Raton. DOI: $10.1201 / 9781003075363$

Randall DJ \& Tsui TK. 2002. Ammonia toxicity in fish. Marine Pollution Bulletin, 45, 17-23.

Rao KS. 2018. Special Commentary on Maximum Acceptable Toxicant Concentration (MATC). BEMS reports, 4(2), 37 - 38 .

Roesma DI, Tjong DH, and Aidil DR. 2020. Phylogenetic analysis of transparent gobies in three Sumatran lakes, inferred from mitochondrial Cytochrome Oxidase I (COI) gene. Biodiversitas, 21(1), 43-48. DOI: $10.13057 /$ biodiv/d210107

Russo RC. 1985. Ammonia, nitrite, and nitrate. In G. M. Rand \& S. R. Petrocelli (Eds.), Fundamentals of aquatic toxicology and chemistry. Hemisphere Publishing Corp., Washington D.C., 455-471.

Tanjung LR. 2015. Kondisi Terkini Kualitas Air dan Tingkat Kesuburan Danau Maninjau. LEMBAGA ILMU PENGETAHUAN INDONESIA. Retrieved Desember 7, 2020. from http://lipi.go.id/publikasi/kondisi-terkinikualitas-air-dan-tingkat-kesuburan-danau$\underline{\text { maninjau/23101 }}$

Thurston RB \& Russo R. 1983. Acute Toxicity of Ammonia to Rainbow Trout. Transactions of the American Fisheries Society, 112(5), 696-704. DOI: $10.1577 / 1548-8659(1983) 112<696$ :ATOA $\mathrm{TR}>2.0 . \mathrm{CO} ; 2$

Tomasso JR, Goudie CA, Simco BA, and Davis KB. 1980. Effects of environmental $\mathrm{pH}$ and calcium on ammonia toxicity in channel catfish. Transactions of the American Fisheries Society, 109(2), 229-234. DOI: 10.1577/1548-8659(1980) 109<229:EOEPAC>2.0.CO;2

USEPA. 1998. Guidelines for risk assessment. U.S. Environmental Protection Agency, Washington, DC.

USEPA. 2002. Methods for Measuring the Acute Toxicity of Effluents and Receiving Waters to Freshwater and Marine Organisms (5th ed.). U.S. Environmental Protection Agency Office of Water, (4303T)1200 Pennsylvania Avenue, NW; Washington, DC 20460. EPA-821-R-02-012 
USEPA. 2013. Aquatic Life Ambient Water Quality Criteria for Ammonia - Freshwater. U.S. Environmental Protection Agency Office of Water Office of Science and Technology; Washington, DC.

Yoga GP \& Nursodiyanti S. 2018. Toksisitas Amonia terhadap benih Ikan Sidat (Anguilla bicolor). Prosiding Seminar Nasional Ikan, 10, 335 - 343.

Yoga GP \& Samir O. 2020. Ammonia toxicity to endemic fish (Rasbora maninjau) of Lake Maninjau as a reference for water quality guidelines. IOP Conference Series: Earth and Environmental Science, 525, 1-7. DOI: $10.1088 / 1755-1315 / 535 / 1 / 012009$

Yosmeri. 2013. Status perkembangan usaha budidaya ikan dengan karamba jaring apung di Danau Maninjau, Sumatera Barat" (State of cage aquaculture business development in Lake Maninjau, West Sumatera). Workshop on Environmental Management of cage aquaculture in open waters (3 - 4 October 2013 ed.). Directorate General of Aquaculture, Ministry of Marine and Fisheries. 